\title{
PENERAPAN MODEL PEMBELAJARAN NUMBERED HEAD TOGETHER (NHT) UNTUK MENINGKATKAN AKTIVITAS BELAJAR IPA
}

\author{
Ni Kadek Adhi Susi Tri Mahartini ${ }^{1}$, I Gede Astra Wesnawa ${ }^{2}$ \\ 1,2Jurusan Pendidikan Guru Sekolah Dasar, Fakultas IImu Pendidikan \\ Universitas Pendidikan Ganesha \\ Singaraja, Indonesia
}

Susimahartini05@gmail.com,gede_astrawesnawa@yahoo.co.id

\begin{abstract}
Abstrak
Penelitian ini bertujuan untuk meningkatkan aktivitas belajar IPA melalui penerapan strategi Numbered head Together pada siswa kelas IV SD N0 1 Kuwum Tahun Pelajaran 2016/2017 Kecamatan Mengwi. Jenis penelitian ini adalah penelitian tindakan kelas (PTK) yang dilaksanakan dalam bentuk siklus. Subjek penelitian ini adalah siswa kelas VI SD N0 1 Kuwum yang berjumlah 9 orang. Objek penelitian adalah Aktivitas belajar IPA. Pengumpulan data dalam penelitian ini dilakukan dengan Observasi. Data yang didapatkan selanjutnya dianalisis untuk mengetahui adanya peningkatan aktivitas belajar IPA pada siswa kelas VI SD NO 1 Kuwum. Hasil penelitian menunjukkan adanya peningkatan terhadap Aktivitas belajar IPA siswa. pada refleksi awal ratarata aktivitas belajar siswa secara klasikal hanya mencapai 14,7 yang berada pada kategori cukup aktif, meningkat pada siklus I sebesar 21,55 yang berada pada kategori aktif. Setelah diadakan perbaikan pada siklus II skor aktivitas belajar IPA siswa secara klasikal sebesar 28,66 yang berada pada kategori sangat aktif. Dengan peningkatan skor rata-rata aktivitas belajar siswa dari refleksi awal ke siklus I sebesar 6,85 dan dari siklus I ke siklus II sebesar 7,11. Berdasarkan hasil penelitian tersebut, dapat disimpulkan bahwa penerapan Model pembelajaran NHT( Numbered Head Together )dapat meningkatkan Aktivitas belajar IPA Pada siswa kelasVI SD NO 1 Kuwum.
\end{abstract}

Kata kunci: Model Pembelajaran NHT, Aktivitas Belajar IPA.

\begin{abstract}
This study aims to improve the sains study activites through the implementation Numbered Head Together learning model. This study was an action research. The research subject was VI class of primary school number 1 Kuwum in which consists of 9 student. The data were analyzed by using descriptive statistical analysis. The result showed that, implementasi Numbered Head Together strategy can increase the activity outcome are characterized by an increase in the average score of student learning activities in the classical style of the early reflections of 14,7 , in the first cycle to 21,55 , and the second cycle to 28,66 Improvement of student learning activity score early reflection to the first cycle of 6,85 , and from the first cycle to the second cycle of 7,11 . Based on the results and discussion, students improved throught implementation Numbered Head Together Strategy to improve activities and long jump in VI class of primary school number 1 Kuwum. fruits academic year 2016/2017
\end{abstract}

Keywords: NHT Learning Model, IPA Learning Activities.

\section{PENDAHULUAN}

Belajar merupakan sebuah kegiatan yang wajib dilakukan oleh peserta didik karena itu merupakan kunci sukses untuk meraih masa depan yang cerah.Untuk mempersiapkan generasi bangsa dengan wawasan ilmu pengetahuan yang tinggi maka diperlukan suatu kegiatan pembelajaran yang efektif dan efisien, dengan harapan kegiatan belajar tersebut menjadi menyenangkan dan tidak membosankan.

Dalam UU No. 20 tahun 2003 tentang sistem pendidikan nasional, pasal1 dinyatakan bahwa : Pendidikan adalah usaha sadar dan terencana untuk mewujudkan suasana belajar dan proses pembelajaran agar 
peserta didik secara aktif mengembangkan potensi dirinya untuk memiliki kekuatan spiritual, keagamaan, pengendalian diri, kepribadian, kecerdasan, akhlak mulia, serta ketrampilan yang diperlukan dirinya, masyarakat, bangsa dan negara.

Permasalahan pun muncul ketika peneliti melakukan pengamatan/observasi pada siswa kelas VI saat melaksanakan pembelajaran IPA di dalam kelas SD No.1 KUWUM. Pada saat pembelajaran minat belajar siswa kurang terhadap pembelajaran IPA, pembelajaran didominasi oleh beberapa siswa, dan siswa masih malu-malu dalam mengemukakan pendapat ataupun jawaban namun sebenarnya mereka tau dan bisa. Gejala-gejala tersebut berdampak pada rendahnya semangat dan aktivitas belajar siswa. Selain itu, melalui pengamatan peneliti juga dapat mengetahui tingkat aktivitas belajar siswa saat pembelajaran berlangsung.

Peneliti

melakukan pengamatan/observasi pada siswa kelas VI SD No 1 Kuwum yang berjumlah 9 orang. Diketahui bahwa, 1 orang siswa tergolong aktif $(11,1 \%)$ terlihat dari keaktifan siswa membaca materi pelajaran tanpa diperintahkan dan menjawab pertanyaan yang diajukan oleh guru. 3 orang siswa tergolong cukup aktif $(33,3 \%)$ terlihat dari cara siswa belajar jika diperintahkan oleh guru untuk mengerjakan tugas atau menjawab pertanyaan guru saat itu siswa baru mau bekerja dan 5 orang siswa tergolong kurang aktif $(55,5 \%)$ terlihat dari keseriusan siswa saat belajar sangat kurang terutama dalam mendengarkan penjelasan.

Berdasarkan data di atas, maka peneliti mengetahui bahwa aktivitas belajar siswa secara klasikal baru mencapai 14,7 yang berada pada katagori Kurang aktif. Aktivitas belajar siswa dikatakan berhasil minimal berada pada katagori aktif, dilihat dari data di atas secara klasikal yang menunjukkan aktivitas belajar siswa belum memenuhi standar.
Atas dasar paparan di atas, maka hal tersebut sangat menarik untuk di cermati melalui Penelitian Tindakan Kelas (PTK) dengan judul: Penerapan Model Pembelajaran Numbered Head Together (NHT) untuk Meningkatkan Aktivitas Belajar IPA siswa kelas VI di SD No.1 Kuwum Kabupaten Badung Tahun Pelajaran 2016/2017

\section{METODE}

Penelitian ini merupakan Penelitian Tindakan Kelas (PTK) atau Classroom Action Research. PTK memiliki peranan yang sangat penting dan strategis untuk meningkatkan mutu pelajaran melalui suatu tindakan bermakna dengan menggunakan sebuah model atau suatu pendekatan pembelajaran yang diperhitungkan dapat memecahkan masalah atau memperbaiki situasi dan kemudian secara cermat mengamati pelaksanaannya untuk mengukur tingkat keberhasilannya PTK merupakan merupakan suatu pencermatan terhadap kegiatan belajar berupa sebuah tindakan yang sengaja dimunculkan dan terjadi disebuah kelas bersama Arikunto dkk ( 2007).

Penelitian ini berlokasi di ruangan kelas VI SD No 1 kuwum Kabupaten Badung. Penelitian ini dilaksanakan mulai dari tanggal 08 Desember 2016 sampai dengan tanggal 22 Pebruari 2017.Subjek penelitian ini adalah siswa kelas VI SD No.1 Kuwum Tahun Pelajaran 2016/2017 dengan jumlah siswa 9 orang. Siswa putri berjumlah 2 orang dan siswa putra 7 orang. Subjek ini dipilih karena berdasarkan hasil observasi diperoleh hasil bahwa aktivitas belajar siswa secara klasikal mencapai 14,7 yang berada pada katagori cukup aktif, secara klasikal menunjukkan aktivitas belajar belum memenuhi standar.

Objek penelitian tindakan kelas ini adalah aktivitas belajar siswa kelas VI SD No.1 Kuwum terhadap penerapan model pembelajaran NHT. Penelitian tindakan kelas dilaksanakan dalam bentuk siklus berulang dan berkelanjutan yang di dalamnya terdapat empat 
tahapan utama kegiatan yaitu perencanaan (Planning), tindakan (action), observasi dan evaluasi (observation and evaluation), refleksi (reflecting). Arikunto, dkk (dalam Rai Kusuma 2014).

$$
\text { Apabila peneliti sudah }
$$

mengetahui letak keberhasilan dan hambatan dari tindakan yang dilaksanakan pada siklus pertama, maka guru atau peneliti menentukan rancangan tindakan berikut pada siklus kedua. Kegiatan pada siklus kedua merupakan kelanjutan dari keberhasilan pada siklus pertama, namun kegiatan pada siklus kedua mempunyai berbagai tambahan untuk perbaikan pada siklus pertama. Jika pelaksanaan pada siklus kedua telah selesai tetapi peneliti belum merasa puas untuk perbaikan dan peningkatan atas tindakan tersebut, peneliti dapat melanjutkan penelitian ke dalam siklus ketiga dan begitu seterusnya sampai peneliti menemukan hasil yang memuaskan.

Siklus tersebut dapat digambarkan dalam model seperti gambar 1 di bawah ini.

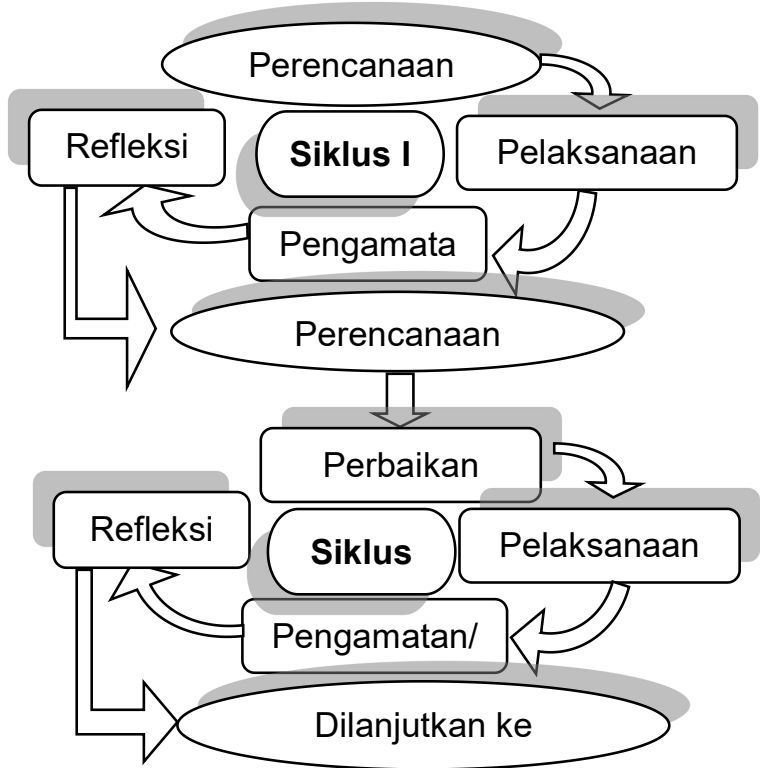

Gambar 1. Model Penelitian Tindakan Kelas (PTK) Sumber: Arikunto ( 2007).

Dalam penelitian ini direncanakan suatu tindakan yang terbagi menjadi dua siklus. Adapun tindakan yang direncanakan pada tiap siklus adalah sebagai berikut. Siklus 1 dilaksanakan dalam 2 kali pertemuan. Dua kali pertemuan ini dilakukan untuk pelaksanaan pembelajar untuk melihat peningkatan aktivitas belajar IPA siswa. Perencanaan tindakan II didasarkan pada hasil refleksi siklus I, kemudian dilakukan perbaikan dengan tidak mengubah substansi seperti pada perencanaan siklus I.

Pelaksanaan tindakan siklus II sama seperti pada siklus I. Terdiri dari 2 kali tindakan sesuai dengan RPP yang telah dibuat. Tindakan yang dilaksanakan pada siklus II merupakan upaya perbaikan hasil yang telah dicapai pada siklus I, sehingga pada siklus II perlu dilakukan penyempurnaan terhadap tindakan yang telah dilakukan pada siklus I.

Instrument penelitian yang digunakan adalah lembar observasi yang sudah berisikan indikator aktivitas belajar siswa. Lembar observasi aktivitas belajar siswa digunakan untuk mengetahui tingkat aktivitas siswa selama proses pembelajaran pada mata pelajaran IPA. Yang mengisi format lembar observasi ini adalah evaluator (guru), di mana cara mengisinya dengan mengisi skor 1 sampai 3 sesuai kemampuan siswa pada kolom-kolom yang telah tersedia sesuai dengan hasil pengamatan evaluator (guru).

Dalam penelitian ini, teknik analisis data yang digunakan adalah analisis deskriptif kuantitatif. Rumus yang digunakan adalah sebagai berikut. Analisis aktivitas belajar IPA siswa

Data aktivitas belajar IPA Siswa secara klasikal $(\overline{X)}$ dianalisis berdasarkan skor kemunculan tiap item aktivitas belajar dalam kegiatan yang dilakukan setiap siswa selama proses pembelajaran dengan menggunakan rumus sebagai berikut:

$\bar{X}=\frac{\sum X}{N}$ (Sudjana, 2004)

Keterangan:

$\bar{X} \quad=$ Rata-rata aktivitas belajar IPA siswa secara (klasikal) 
$\sum X=$ jumlah seluruh skor aktivitas belajar IPA siswa

$\mathrm{N} \quad=$ jumlah siswa

Untuk menentukan aktivitas belajar secara klasikal dianalisis

Tabel 1. Kreteria penggolongan aktivitas belajar siswa

\begin{tabular}{ccc}
\hline No & Kreteria & Kategori \\
\hline 1. & $\bar{X} \geq \mathrm{Mi}+1,5 \mathrm{SDi}$ & Sangat aktif \\
2. & $\mathrm{Mi}+0,5 \mathrm{SDi} \leq \bar{X}<\mathrm{Mi}+1,5 \mathrm{SDi}$ & Aktif \\
3. & $\mathrm{Mi}-0,5 \mathrm{SDi} \leq \bar{X}<\mathrm{Mi}+0,5 \mathrm{SDi}$ & Cukup aktif \\
4. & $\mathrm{Mi}-1,5 \mathrm{SDi} \leq \bar{X}<\mathrm{Mi}-0,5 \mathrm{SDi}$ & Kurang aktif \\
5. & $\bar{X}<\mathrm{Mi}-1,5 \mathrm{SDi}$ & Sangat kurang aktif
\end{tabular}

Keterangan:

Rumus untuk Mi dan SDi adalah

$$
\begin{aligned}
& \mathrm{Mi}=\frac{1}{2} \times \mathrm{SMI} \\
& \mathrm{SDi}=\frac{1}{3} \times \mathrm{Mi}
\end{aligned}
$$

Keterangan:

$\mathrm{Mi}=$ mean ideal (angka rata-rata ideal)

SDI = Standar Deviasi Ideal

(Nurkancana dan Sunartana, 1992)

Data dikumpulkan dengan format observasi terhadap kemunculan indikator aktivitas belajar sesuai dengan yang berdasarkan mean ideal $(\mathrm{Mi})$ dan standar deviasi ideal (SDi) dengan mengkonversikan rata-rata skor ke dalam kreteria sebagai berikut, dapat dilihat pada tabel 1 di bawah ini. tertera pada lembar observasi aktivitas belajar siswa. Berdasarkan hal tersebut dapat ditentukan skor tertinggi (SMI) adalah 36 dan skor terendah adalah 0 . Dengan demikian perhitungan $\mathrm{Mi}$ dan SDi adalah sebagai berikut.

$$
\begin{aligned}
\text { Mi } & =\frac{1}{2} \times 36 \\
& =18 \\
\text { SDi } & =\frac{1}{3} \times 18 \\
& =6
\end{aligned}
$$

Pedoman penggolongan aktivitas siswa selanjutnya dapat dinyatakan seperti pada table 2 di bawah ini.

Tabel 2 Pedoman Penggolongan Aktivitas Belajar IPA Siswa

\begin{tabular}{ccc}
\hline No & Kreteria & Kategori \\
\hline 1. & $\bar{X} \geq 27$ & Sangat aktif \\
2. & $21 \leq \bar{X}<27$ & Aktif \\
3. & $15 \leq \bar{X}<21$ & Cukup aktif \\
4. & $9 \leq \bar{X}<15$ & Kurang aktif \\
5. & $\bar{X}<9$ & Sangat kurang aktif
\end{tabular}

Penelitian tindakan kelas ini dikatakan berhasil apabila aktivitas belajar siswa minimal berada pada katagori aktif, baik secara individu maupun klasikal.

\section{HASIL DAN PEMBAHASAN}

Sesuai dengan permasalahan yang diungkapkan pada bagian pendahuluan, dilaksanakanlah suatu penerapan pembelajaran menggunakan model pembelajaran NHT pada mata pelajaran IPA siswa kelas VI SD No 1 Kuwum, Kabupaten Badung, sesuai dengan rencana pelaksanaan pembelajaran yang telah disusun sebelumnya untuk pertemuan tiap siklus (siklus I dan siklus II). Pada rencana pelaksanaan pembelajaran tiap siklus secara umum menguraikan tentang kegiatan pendahuluan, kegiatan inti, dan kegiatan penutup.

Data yang dikumpulkan dalam penelitian ini, yaitu data tentang aktivitas belajar IPA siswa terhadap pembelajaran yang dilaksanakan. Data yang telah dikumpulkan dianalisis sesuai dengan teknik analisis data yang telah ditetapkan 
sebelumnya. Adapun rincian mengenai data tersebut dapat diuraikan sebagai berikut.

Hasil Penelitian Aktivitas Belajar IPA Siswa pada Siklus I Aktivitas belajar IPA siswa pada siklus I diperoleh dengan cara menggabungkan nilai yang diperoleh oleh masing-masing individu pada pertemuan 1 pada tanggal 23 Januari 2017 dari pukul 07.30-08.40 wita dan pertemuan II pada tanggal 30 januari 2017 dari pukul 09.30-10.40 wita. Hasil penelitian pada siklus I dilaksanakan sesuai dengan rencana pelaksanaan pembelajaran yang telah disusun pada Lampiran 15. Selama pembelajaran berlangsung guru/teman sejawat sebagai observer berperan untuk mengamati aktivitas belajar siswa selama dua kali pertemuan dalam I siklus.( sesuai dengan Format Lembar Aktivitas Belajar IPA Siswa pada Lampiran 3) Dari nilai yang diperoleh oleh tiap individu pada pertemuan I dan II, selanjutnya digabung dan dibagi dua, sehingga diperoleh skor akhir aktivitas belajar siswa secara individu pada siklus I.

Dari seluruh skor yang diperoleh oleh masing-masing individu selanjutnya dijumlahkan secara keseluruhan dan dibagi banyaknya jumlah siswa yaitu 9 orang siswa, sehingga akan diperoleh aktivitas belajar siswa secara klasikal. Rekapitulasi data aktivitas belajar IPA siswa pada siklus I dapat dilihat pada tabel 3 di bawah ini.

Tabel 3. Rekapitulasi Data Aktivitas Belajar IPA Siswa Kelas VI SD No. 1 Kuwum Pada Siklus I

\begin{tabular}{|c|c|c|c|c|}
\hline \multirow[b]{2}{*}{ Kode siswa } & \multicolumn{3}{|c|}{ Jumlah Nilai Evaluator } & \multirow[b]{2}{*}{ Kategori } \\
\hline & $\begin{array}{c}\text { Pertemuan } \\
\mid\end{array}$ & $\begin{array}{c}\text { Pertemuan } \\
\text { II }\end{array}$ & Skor Akhir & \\
\hline 01 & 20 & 24 & 22 & A \\
\hline 02 & 20 & 24 & 22 & $A$ \\
\hline 03 & 16 & 20 & 18 & $C A$ \\
\hline 04 & 14 & 18 & 16 & $\mathrm{CA}$ \\
\hline 05 & 25 & 26 & 25,5 & A \\
\hline 06 & 16 & 17 & 16,5 & CA \\
\hline 07 & 29 & 30 & 29,5 & S A \\
\hline 08 & 27 & 28 & 27,5 & S A \\
\hline 09 & 14 & 20 & 17 & CA \\
\hline \multicolumn{2}{|c|}{ Jumlah } & \multicolumn{3}{|c|}{194} \\
\hline \multicolumn{2}{|c|}{ Rata-rata } & & 21,55 & \\
\hline
\end{tabular}

Dari table 3, hasil observasi aktivitas belajar siswa secara individu dapat dimasukkan ke dalam pedoman

Tabel 4. Kategori Penggolongan Aktivitas Belajar IPA Siswa Kelas VI SD No.1 Kuwum Pada Siklus I

\begin{tabular}{lcccc}
\hline No & Kreteria & $\begin{array}{c}\text { Jumlah } \\
\text { siswa }\end{array}$ & $\begin{array}{c}\text { Presentase } \\
(\%)\end{array}$ & Kategori \\
\hline 1. & $\bar{X} \geq 27$ & 2 & 22,2 & Sangat aktif \\
2. & $21 \leq \bar{X}<27$ & 3 & 33.3 & Aktif \\
3. & $15 \leq \bar{X}<21$ & 4 & 44,4 & Cukup aktif \\
4. & $9 \leq \bar{X}<15$ & - & - & Kurang aktif \\
\hline & Total & 9 & 100 & \\
\hline
\end{tabular}

penggolongan aktivitas belajar siswa seperti tabel 3. 
Untuk lebih jelasannya dapat dilihat pada Diagram :

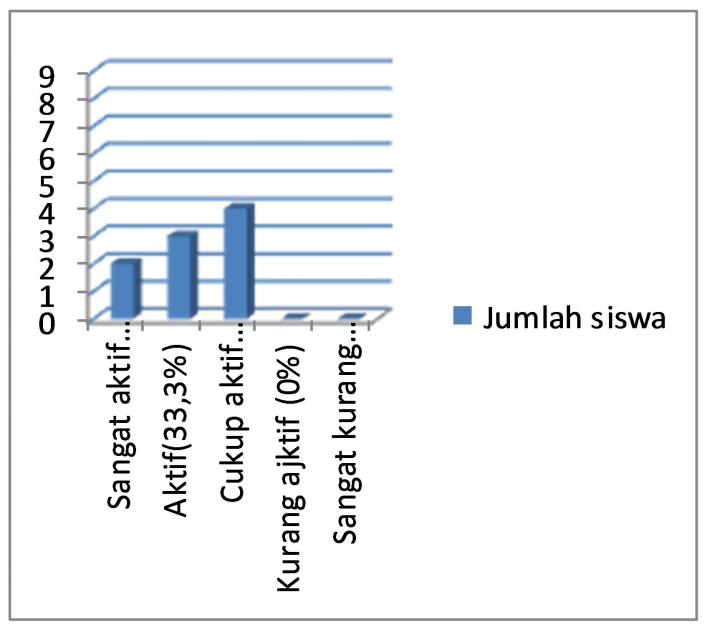

Gambar 2 Diagram Aktivitas Belajar IPA Siswa Siklus I.

Dari diagram di atas dapat dijelaskan bahwa pada siklus I, diperoleh data aktivitas belajar IPA siswa secara individu yaitu, siswa yang berada pada kategori sangat aktif sebanyak 2 orang $(22,2 \%)$, aktif 3 orang $(33,3 \%)$, cukup aktif 4 orang $(44,4 \%)$, kurang aktif 0 orang $(0 \%)$ dan sangat kurang aktif 0 orang $(0 \%)$.

Berdasarkan observasi aktivitas belajar IPA siswa di kelas VI SD No.1 Kuwum pada siklus I, diketahui jumlah seluruh skor yang diberikan oleh evaluator (guru/teman sejawat) dalam dua kali pertemuan sebesar 194 .Dari hasil tersebut dapat diketahui rata-rata aktivitas belajar IPA siswa secara klasikal $(\bar{X})$ adalah sebagai berikut :

$$
\begin{aligned}
\bar{X} & =\frac{\sum X}{N} \\
& =\frac{194}{9} \\
& =21,55
\end{aligned}
$$

Hasil 21,55 jika dimasukkan ke dalam kategori yang telah dibuat pada bab III tentang pedoman penggolongan aktivitas belajar siswa, maka aktivitas belajar siswa secara klasikal pada siklus I masuk ke dalam kategori aktif. Dengan demikian dapat disimpulkan, bahwa aktivitas belajar siswa secara klasikal pada siklus I sudah memenuhi kriteria ketuntasan yang ditentukan yaitu aktivitas belajar siswa dikatakan berhasil minimal berada pada katagori aktif baik secara klasikal maupun individu.

Walaupun secara klasikal aktivitas belajar siswa sudah memenuhi kriteria ketuntasan, namun ada 4 orang siswa yang belum memenuhi kriteria ketuntasan secara individu dalam aktivitas belajar. Jadi penelitian pada siklus I secara individu dinyatakan belum tuntas karena belum mencapai indikator keberhasilan yang telah ditetapkan sebelumnya, pada bab III. Dengan demikian maka perlu diadakan suatu perbaikan melalui siklus berikutnya yaitu siklus II.

Berdasarkan data yang diperoleh sampai akhir siklus I, dapat direfleksikan beberapa hal sebagai berikut. Pertama Siswa belum memahami model pembelajaran yang digunakan guru, dalam hal ini model yang digunakan adalah model pembelajaran Numbered Head Together (NHT), keduan Kurang adanya penekanan terkait aturan bermain, kesepakatan, dan ganjaran yang diberikan saat melakukan permainan (game), ketiga Siswa di masing-masing kelompok masih ragu/bingung untuk maju ke depan kelas, disaat nomor yang disebutkan oleh peneliti maju untuk memecahkan masalah yang sebelumnya telah dibahas di kelompok, keempat Selama pembelajaran, $\pm 50 \%$ aktivitas dan kerjasama belajar siswa, baik secara individu atau kelompok masih tampak rendah, pembelajaran didominsi oleh beberapa orang siswa dan yang lainnya tampak vakum (diam tidak bekerja), kurang memperhatikan pelajaran, dan perkataan guru (dalam hal ini adalah peneliti) sehingga tampak bahwa, minat dan semangat belajar siswa kurang., kelima Saat siswa disarankan untuk membentuk kelompok keadaan/suasana kelas tampak gaduh dan ribut.

Hambatan-hambatan di atas secara umum disebabkan karena siswa belum terbiasa dengan pembelajaran yang dilakukan. Tapi secara umum siswa menyukai implementasi model pembelajaran Numbered Head Together dalam pembelajaran, karena berisi permainan, meningkatkan konsentrasi, 
dan juga dapat mengaktifkan siswa untuk berpikir kritis/cepat.

Mengacu pada hasil refleksi dan kekurangan yang dihadapi pada siklus I, maka peneliti melakukan perbaikan untuk merancang tindakan yang dilanjutnya ke siklus II untuk lebih mengoptimalkan hasil yang diperoleh. Upaya yang dilakukan untuk mengoptimalkan hasil yang diperoleh yaitu sebagai berikut: 1) Peneliti menjelaskan lebih detail terkait model yang digunakan untuk menambah pemahaman siswa terkait model pembelajaran Numbered Head Together (NHT), 2) Peneliti lebih mempertegas aturan main, kesepakatan, dan ganjaran yang diberikan saat melakukan permainan (game), 3) Peneliti memperjelas dan mempertegas, bahwa setiap nomor yang dipanggil oleh guru untuk maju ke depan kelas dalam memecahkan masalah yang sudah dibahas sebelumnya dalam kelompok, diwakilkan oleh masing-masing siswa (dalam kelompok) yang memegang nomor yang sama. Misalnya: guru memenggil nomor urut 2, maka perwakilan tiap-tiap kelompok yang memegang nomor urut 2 semuanya maju ke depan kelas untuk memecahkan masalah, 4) Meningkatkan aktivitas belajar siswa baik secara kelompok atau individu, ialah dengan memberikan penguatan kepada siswa berupa reward agar siswa lebih termotivasi dalam pembelajaran sehingga berpengaruh pada kesungguhan belajar siswa serta mampu meningkatkan minat dan semangat siswa. Dalam mengerjakan tugas, dilakukan pembagian kerja secara merata dalam kelompok, selain itu siswa juga disuruh membuat jawaban di buku tugas masing-masing terkait LKS yang dibahas, hal ini dilakukan agar siswa tidak diam/vakum dalam kelompok dan mengurangi aktivitas bermain siswa.
Siswa yang kemampuannya agak kurang dapat dibantu oleh siswa lain yang lebih pandai dalam kelompoknya. Sehingga dengan demikian masing-masing siswa dalam kelompok memiliki tanggung jawab terhadap tugas yang diberikan. Saat pembentukan kelompok siswa lebih diogrganisir agar tidak rebut saat membentuk kelompok sehingga waktu untuk pembentukan kelompok tidak terkuras banyak.

Hasil Penelitian Aktivitas Belajar IPA Siswa pada Siklus II Aktivitas belajar IPA siswa pada siklus II diperoleh dengan cara menggabungkan nilai yang diperoleh oleh masing-masing individu pada pertemuan 1 tanggal 14 pebruari 2017 dari pukul dari pukul 07.30-08.40 wita dan pertemuan II pada tanggal 21 februari 2017 dari pukul 09.30-10.40 wita.

Hasil penelitian pada siklus II dilaksanakan sesuai dengan rencana pelaksanaan pembelajaran yang telah disusun (terdapat pada lampiran 16). Selama pembelajaran berlangsung guru/teman sejawat sebagai observer berperan untuk mengamati aktivitas belajar siswa selama dua kali pertemuan dalam I siklus. .( sesuai dengan Format Lembar Aktivitas Belajar IPA Siswa pada Lampiran 3) Dari nilai yang diperoleh oleh tiap individu pada pertemuan I dan II, selanjutnya digabung dan dibagi dua, sehingga diperoleh skor akhir aktivitas belajar siswa secara individu pada siklus II.

Dari seluruh skor yang diperoleh oleh masing-masing individu selanjutnya dijumlahkan secara keseluruhan dan dibagi banyaknya jumlah siswa (9 orang siswa), sehingga akan diperoleh aktivitas belajar siswa secara klasikal. Rekapitulasi data aktivitas belajar IPA siswa pada siklus II dapat dilihat pada Tabel 5

Tabel 5. Rekapitulasi Data Aktivitas Belajar IPA Siswa Kelas VI SD No. 1 Kuwum Pada siklus II

\begin{tabular}{lcccc}
\hline \multirow{2}{*}{ Kode siswa } & \multicolumn{3}{c}{ Jumlah Nilai Evaluator } & \multirow{2}{*}{ Kategori } \\
\cline { 2 - 4 } & $\begin{array}{c}\text { Pertemuan } \\
\text { I }\end{array}$ & $\begin{array}{c}\text { Pertemuan } \\
\text { II }\end{array}$ & Skor Akhir & \\
\hline 01 & 27 & 30 & 28,5 & S A
\end{tabular}

286 Journal of Education Action Research 


\begin{tabular}{|c|c|c|c|c|}
\hline 02 & 28 & 31 & 29,5 & $S A$ \\
\hline 03 & 25 & 28 & 26,5 & A \\
\hline 04 & 24 & 26 & 25 & A \\
\hline 05 & 30 & 32 & 31 & SA \\
\hline 06 & 24 & 28 & 26 & A \\
\hline 07 & 32 & 33 & 32,5 & SA \\
\hline 08 & 30 & 32 & 31 & $S A$ \\
\hline 09 & 26 & 30 & 28 & SA \\
\hline \multicolumn{2}{|c|}{ Jumlah } & \multicolumn{3}{|c|}{258} \\
\hline \multicolumn{2}{|c|}{ Rata-rata } & \multicolumn{3}{|c|}{28,66} \\
\hline
\end{tabular}
dapat dimasukkan ke dalam pedoman

Tabel 6

Kategori Penggolongan Aktivitas Belajar IPA Siswa Kelas VI SD No.1 Kuwum Pada Siklus II

\begin{tabular}{lcccc}
\hline No & Kreteria & Jumlah siswa & $\begin{array}{c}\text { Presentase } \\
(\%)\end{array}$ & Kategori \\
\hline 1. & $\bar{x} \geq 27$ & 6 & 66,6 & SA \\
\hline 2. & $21 \leq \bar{x}<27$ & 3 & 33,3 & $\mathrm{~A}$ \\
\hline 3. & $15 \leq \bar{x}<21$ & - & - & $\mathrm{CA}$ \\
\hline 4. & $9 \leq \bar{x}<15$ & - & - & KA \\
\hline 5. & $\bar{x}<9$ & - & - & SKA \\
\hline & Total & 9 & 100 & \\
\hline
\end{tabular}

Untuk lebih jelasannya dapat dilihat pada diagram :

Gambar 3 Diagram Aktivitas Belajar IPA Siswa Siklus II

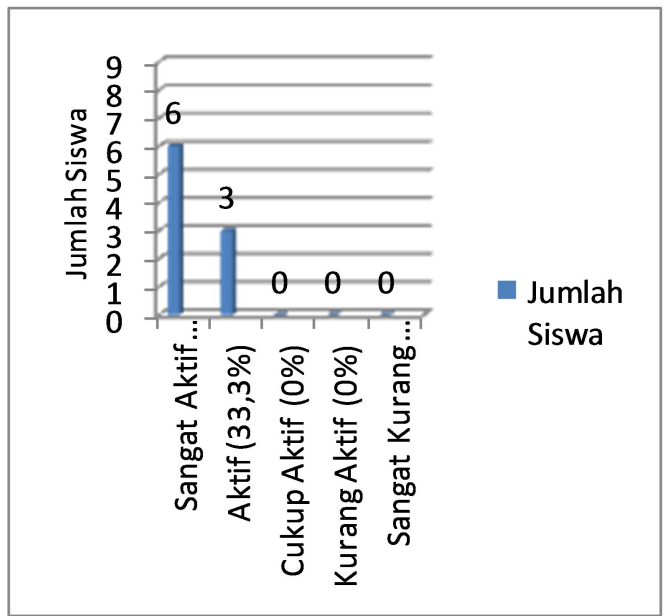

Dari Gambar 3 dapat dijelaskan bahwa, berdasarkan hasil pengamatan dan hasil analisis data tentang aktivitas belajar siswa pada siklus II, diperoleh data aktivitas belajar IPA siswa secara individu yaitu, siswa yang berada pada kategori sangat aktif sebanyak 6 orang $(66,6 \%)$, aktif sebanyak 3 orang (33,3\%)cukup aktif, kurang aktif dan sangat kurang aktif tidak ada (0\%).
Berdasarkan observasi aktivitas belajar IPA siswa kelas VI SD No.1 Kuwum pada siklus II, diketahui jumlah seluruh skor yang diberikan oleh evaluator (guru/teman sejawat) dalam dua kali pertemuan sebesar 258. Dari hasil tersebut dapat diketahui rata-rata aktivitas belajar IPA siswa secara klasikal $(\bar{X})$ adalah sebagai berikut.

$$
\begin{aligned}
\bar{X} & =\frac{\sum X}{N} \\
& =\frac{258}{9} \\
& =28,66
\end{aligned}
$$

Hasil 28,66 jika dimasukkan ke dalam kategori yang telah dibuat pada bab III tentang pedoman penggolongan aktivitas belajar siswa, maka aktivitas belajar siswa pada siklus II termasuk ke dalam kategori sangat aktif.

\section{Hasil Refleksi Siklus I}

Melalui observasi tindakan yang sudah dilakukan pada siklus II dan merupakan tindak lanjut dari pelaksanaan tindakan siklus I. Ternyata yang menjadi kendala pada siklus I dapat terpecahkan pada siklus II. Hal ini 
terbukti dengan adanya peningkatan aktivitas belajar siswa. Adapun interpretasi data peningkatan aktivitas belajar siswa, dapat dilihat pada Tabel 7

Tabel 7 Interpretasi Data Aktivitas Belajar IPA Siswa

\begin{tabular}{|c|c|c|c|}
\hline Tahapan & $\begin{array}{c}\text { Rata-rata Skor Aktivitas } \\
\text { Belajar IPA Siswa }\end{array}$ & $\begin{array}{c}\text { Rata-rata Peningkatan } \\
\text { Skor Aktivitas Belajar } \\
\text { Siswa }\end{array}$ & Kategori \\
\hline Refleksi Awal & 14,7 & - & Kurang Aktif \\
\hline Siklus I & 21,55 & 6,85 & Aktif \\
\hline Siklus II & 28,66 & 7,11 & Sangat Aktif \\
\hline Siklus I & 21,55 & 6,85 & Aktif \\
\hline
\end{tabular}

Untuk lebih jelasannya dapat dilihat pada diagram :

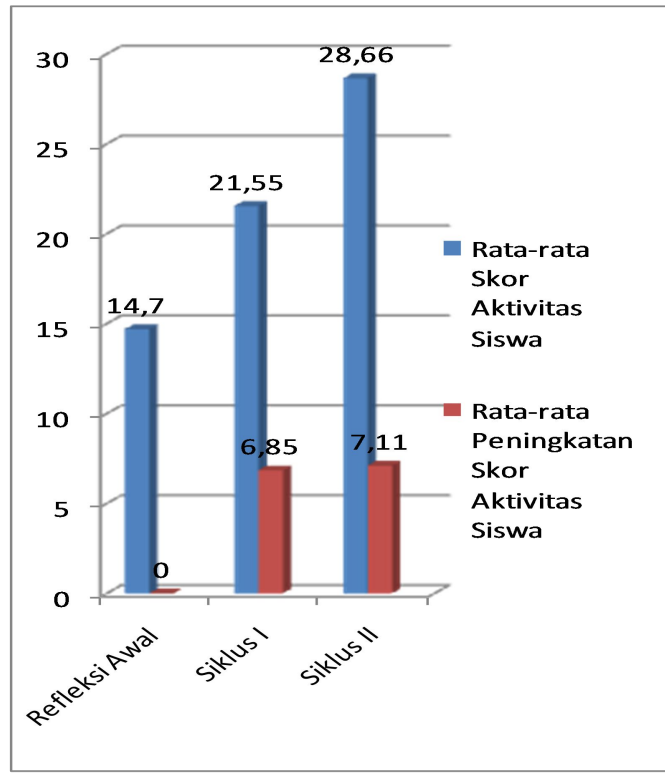

Dari Gambar 4. dapat dijelaskan bahwa, pada refleksi awal rata-rata aktivitas belajar siswa secara klasikal hanya mencapai 14,7 yang berada pada kategori cukup aktif, meningkat pada siklus I sebesar 21,55 yang berada pada kategori aktif. Setelah diadakan perbaikan pada siklus II skor aktivitas belajar IPA siswa secara klasikal sebesar 28,65 yang berada pada kategori sangat aktif. Dengan peningkatan skor rata-rata aktivitas belajar siswa dari observasi awal ke siklus I sebesar 6,85 dan dari siklus I ke siklus II sebesar 28,65

Berdasarkan analisis data pada refleksi awal diketahui bahwa rata-rata aktivitas belajar siswa secara klasikal pada refleksi awal yaitu sebesar 14,7 yang berada pada kategori cukup aktif, sehingga aktivitas belajar IPA siswa belum memenuhi standar Indikator keberhasilan aktivitas belajar siswa dalam penelitian ini yaitu apabila aktivitas belajar siswa berada pada kategori aktif, baik secara individu maupun klasikal.

Maka dari itu, diadakanlah suatu perbaikan melalui penelitian tindakan kelas dalam pola siklus. Penelitian ini diadakan dalam 2 siklus dengan menerapkan model pembelajaran NHT. Siklus pertama setelah diterapkan model pembelajaran NHT diketahui bahwa ratarata aktivitas belajar IPA siswa secara klasikal mencapai 21,55 berada pada kategori aktif, penelitian pada siklus I secara klasikal sudah memenuhi indikator keberhasilan yang telah ditentukan yaitu aktivitas belajar siswa berada pada kategori aktif, namun masih ada 4 orang siswa secara individu belum memenuhi indikator keberhasilan yang telah ditetapkan pada bab III, maka dari itu penelitian dilanjutkan ke siklus II.

Pada siklus II setelah diadakan perbaikan berdasarkan hasil refleksi siklus I dalam pembelajaran, dengan menerapkan model pembelajaran NHT diketahui aktivitas belajar IPA siswa meningkat menjadi 28,66 dimana, 6 orang berada pada kategori sangat aktif dan penelitian ini dihentikan karena sudah melampaui target yang sudah ditentukan pada indikator keberhasilan yaitu berada pada kategori aktif baik secara individu maupun klasikal. Hal ini menandakan bahwa adanya peningkatan aktivitas belajar IPA siswa sebelum tindakan sampai setelah diadakan tindakan dengan penerapan model pembelajaran NHT. 
Peningkatan aktivitas belajar IPA siswa dari sebelum tindakan sampai setelah diadakan tindakan disebabkan karena melalui penerapan model pembelajaran Numbered Head Together yang memiliki ciri khusus penomoran pada tiap siswa dapat mengaktifkan siswa saat belajar karena siswa bisa belajar sambil bermain (melakukan game) sehingga pembelajaran tidak membosankan namun menyenangkan selain itu juga melalui penerapan model pembelajaran ini melatih siswa untuk berpikir kritis, meningkatkan rasa ingin tahu, rasa percaya diri, bertanggung jawab, berkerjasama dan menanamkan sikap saling menghargai.

Dengan demikian secara tidak langsung siswa lebih giat untuk belajar. Hal ini sejalan dengan pendapat Risa dan setiyo (dalam Rai Kusuma 2014) menjelaskan bahwa NHT merupakan model pembelajaran yang mengutamakan adanya kerjasama antar siswa dalam kelompok untuk mencapai tujuan pembelajaran. sebagian besar aktifitas pembelajaran berpusat pada siswa, yakni mempelajari materi pelajaran serta berdiskusi.untuk memecahkan masalah. Dengan pemilihan model ini, diharapkan pembelajaran yang terjadi dapat lebih bermakna dan memberi kesan yang kuat kepada siswa.

Senada dengan hal tersebut Isjoni dan Ismail (dalam Rai Kusuma 2014) menyatakan bahwa Model pembelajaran kooperatif Tipe NHT mempunyai beberapa kelebihan yaitu :meningkatkan prestasi belajar, rasa ingin tahu, rasa percaya diri, kerja sama, komunikasi antar peserta didik, dan membantu peserta didik belajar menggunakan sopan santun serta menghargai pendapat orang lain.

$$
\text { Dalam penerapan model }
$$

pembelajaran NHT dengan

menggunakan bantuan LKS saat diskusi dapat meningkatkan keaktifan siswa dalam menyelesaikan permasalahan yang diberikan oleh guru, melatih siswa untuk bertanggung jawab, membantu siswa yang memiliki kemampuan rendah dalam belajar sehingga siswa tersebut dapat megikuti dan menyelesaikan pelajaran dengan baik, dapat meningkatkan interaksi antara siswa dalam kelompok serta dapat menumbuhkan sikap saling menghargai antar sesama kelompok. Temuan ini sejalan dengan pendapat Muryanto (2009) menyatakan bahwa terdapat beberapa alasan yang mendasari diterapkannya LKS dalam pembelajaran, yaitu: jumlah siswa yang gagal dan menunjukkan kinerja (performance) yang tidak memuaskan dapat dikurangi secara nyata, dengan itu didukung oleh hasil penelitian.

Pola ini memberikan kesempatan, baik pada siswa yang lamban maupun cepat untuk menyelesaikan pelajaran sesuai dengan kemampuan masingmasing dalam situasi yang cocok. Metode ini menyebabkan lebih banyak perhatian tercurah pada siswa dan memberikan kesempatan yang seluasluasnya untuk berlangsungnya interaksi antara siswa dengan siswa, dan guru dengan siswa. Rasa percaya diri dan tanggung jawab pribadi yang dituntut dari siswa, mungkin dapat berlanjut sebagai kebiasaan dalam kegiatan pendidikan yang lain, tanggung jawab atas pekerjaan, dan tingkah laku pribadi.

\section{SIMPULAN DAN SARAN}

Berdasarkan hasil analisis data dan pembahasan, maka dapat disimpulkan hal-hal bahwa implementasi model pembelajaran Numbered Head Together (NHT) dapat meningkatkan aktivitas belajar IPA pada siswa kelas VI di SD No.1 Kuwum tahun pelajaran 2016/2017. Hal ini dapat dilihat dari semakin meningkatnya aktivitas belajar IPA siswa. Pada refleksi awal rata-rata aktivitas belajar siswa secara klasikal hanya mencapai 14,7 yang berada pada kategori cukup aktif, meningkat pada siklus I aktivitas belajar siswa secara klasikal sebesar 21,55 yang berada pada kategori aktif. Setelah diadakan perbaikan pada siklus II skor aktivitas belajar IPA siswa secara klasikal sebesar 28,66 yang berada pada kategori sangat aktif. Dengan 
peningkatan skor rata-rata aktivitas belajar siswa dari refleksi awal ke siklus I sebesar 6,85 dan dari siklus I ke siklus II sebesar 7,11

Berdasarkan simpulan di atas, adapun saran-saran yang akan disampaikan adalah sebagai berikut. Pertama Guru sekolah dasar diharapkan mencoba penerapan model pembelajaran $\mathrm{NHT}$, karena dapat meningkatkan aktivitas belajar siswa. Melalui model pembelajaran NHT. yang memiliki ciri khusus penomoran pada masing-masing siswa akan dapat meningkatkan rasa tanggung jawab, rasa percaya diri, sikap saling menghargai, serta mampu mengaktifkan siswa baik dari segi berpikir maupun kerjasama dalam kelompok, selain itu melalui model ini siswa juga dapat belajar sambil bermain. Sehingga dengan demkian pembelajaran akan lebih menyenangkan. Di samping itu, bila guru ingin mengembangkan kompetensi siswa sebaiknya guru selalu memilih dan mencoba model-model pembelajaran inovatif yang memungkinkan dapat mengembangkan kompetensi siswa. kedua Sekolah dapat menjadikan pedoman terutama dalam pelajaran IPA dan juga pelajaran-pelajaran lainnya yang memungkinkan model ini dapat diterapkan. Ketiga Pembaca/calon peneliti yang berminat untuk mengadakan penelitian lebih lanjut tentang implementasi model pembelajaran Number Head Together (NHT) disarankan memerhatikan kendala-kendala yang peneliti dialami ataupun faktor-faktor lain yang mungkin dapat memengaruhi hasil penelitian, untuk selanjutnya dapat dijadikan bahan pertimbangan untuk dapat membuat rancangan penelitian yang lebih sempurna.

\section{DAFTAR PUSTAKA}

Aisyah, Nyimas, dkk. 2008. Pengembangan Pembelajaran $S D$. Direktorat Jendral Pendidikan Tinggi Departemen Pendidikan Nasional.
Arikunto, Suharsimi dkk. 2007. Penelitian Tindakan Kelas. Jakarta: Bumi Aksara

Arikunto, Suharsimi dkk. 2010. Penelitian Tindakan Kelas. Jakarta: Bumi Aksara.

Undang-undang RI No. 20 Tahun 2003 tentang Sistem Pendidikan Nasional. Jogjakarta: BENING.

Ibrahim, Muslimin dkk. 2001. Pembelajaran Kooperatif. Surabaya: University Press.

Januadi, Wawan. 2010. Aktivitas Belajar Siswa. Tersedia pada http://wawanjunaidi.blogspot.com/ 2010/07/aktivitasbelajarsiswa.html. Diakses tanggal 12 April 2013.

Konsorsium Sertifikasi Guru.2013. Penelitian Tindakan Kelas. Singaraja.

Muryanto, S. A. 2009. LKS oh LKS. Tersedia pada http://andy.web.id//ks-oh-lks.php. Diakses tanggal 12 April 2013.

Moedjiono, \& Moh. Dimyanti. 1992. Strategi Belajar Mengajar. Jakarta: Depdikbud Direktorat Jendral Pendidikan Tinggi Proyek Pembinaan Kependidikan.

Tenaga

Nurhadi, dkk. 2004. Pembelajaran Kontekstual dan Penerapannya dalam KBK. Surabaya: Universitas Negeri Malang

Nurkancana dan Sunartana. 1992. Evaluasi Hasil Belajar. Surabaya: Jendral Pendidikan Tinggi Departemen Pendidikan dan Kebudayaan.

Rai Kusuma. 2014. Penerapan Model Pembelajaran Numbered Head Together untuk Meningkatkan AktivitasBelajar PKN pada Siswa kelas $v$ SD No 3 Sembung Kabupaten Badung Tahun Pelajaran 2013/2014

Sumantri, Mulyani dan Johar Permana.1998. Strategi Belajar mengajar. Jakarta: Depdikbud Dirjendikti Proyek pendidikan Guru Sekolah Dasar

Sudjana, Nana. 2004.Penilaian Hasil Proses Belajar 
Mengajar.bandung:

PT Remaja Rosdakarya.

Sardiman. 2011. Interaksi dan Motivasi

Belajar Mengajar. Jakarta: PT Raja Grafindo Persada.

Sudana, Kusmariyanti.2013.Pendidikan Ipa Sd. Fakultas IImu Pendidikan Universitas Pendidikan

Ganesha.Singaraja

Sukrama. 2012.Penerapan Pendekatan Keterampilan Proses dengan Metode Pemberian Tugas untuk Meningkatkan Keaktifan dan Prestasi Belajar Siswa dalam Pelajaran Matematika Siswa Kelas III Sekolah Dasar Negeri 3 Sambangan Tahun Pelajaran 2011/2012. Jurusan PGSD, Universitas Pendidikan Ganesha.

Trianto. 2007. Model- Model Pembelajaran Inovatif Berorientasi Konstruktivistik. Jakarta : Prestasi Pustaka. Trianto.2010.Model

Pembelajaran

Terpadu.Jakarta.Bumi Aksara
Agung. 2005. Metodologi Penelitian Pendidikan. Singaraja: Fakultas IImu Pendidikan Institut Keguruan dan IImu Pendidikan Negeri Singaraja.

-------. 2010. Penelitian Tindakan Kelas (Teori dan Analisis Data dalam PTK). Singaraja: Universitas pendidikan Ganesha.

Arsyad, Azhar. 2011. Media Pembelajaran. Jakarta: PT. Raja Grafindo Persada.

Kunandar. 2011. Langkah Mudah Penelitian Tindakan Kelas Sebagai Pengembangan Profesi Guru. Jakarta: PT. Raja Grafindo Persada.

Nurkancana, Wayan dan Sunartana. 1990. Evaluasi Hasil Belajar. Surabaya: Usaha Nasional.

Slavin, Robert. 2008. Cooperative Learning Teory, Riset, dan Praktik. Bandung: Nusa Media.

Somantri, Muhammad Numan. 2001. Menggagas Pembaharuan Pendidikan IPS. Bandung: Remaja Rosda Karya. 